\title{
Southern Rust Disease of Corn - A Review
}

\author{
Srabani Debnath $^{1^{*}}$, Sanjog Chhetri ${ }^{1}$ and Sonali Biswas ${ }^{2}$ \\ ${ }^{1}$ Department of Plant pathology, ${ }^{2}$ Department of Agronomy, Bidhan Chandra Krishi \\ Viswavidyalaya, West Bengal, India \\ *Corresponding author
}

\section{Keywords \\ Biotroph, Epidemiology, Yield Loss, \\ Epidemics, Management \\ Article Info \\ Accepted: \\ 10 October 2019 \\ Available Online: \\ 10 November 2019}

\section{A B S T R A C T}

Maize is having a high yield potential and the problem of increasing demand of food and feed for the growing population can be solved by producing more corn in the coming years. Among the constraints faced by this cereal crop, one is the biotic stress. Rust is a very important disease problem of corn and specially the southern corn rust may pose a serious threat to maize production. Southern Rust pathogen is a biotroph and cannot exist without living host. So, it is very important to study this disease thoroughly considering its mode of spread, epidemiology, yield loss, occurrence of epidemics in different countries and most importantly the management strategies that can be followed in minimizing the yield loss due to this disease. In this article specially these important issues of southern corn rust is discussed in detail.

\section{Introduction}

Maize (Zea mays L.) is one of the major cereal crops in the world as well as in India. It is used in diversified ways and known as the queen of cereals because of its highest yield potential among all the cereal crops. Maize crop may be affected by 112 biotic stresses. Rust disease of corn is one of the important diseases of maize. There are three types of rusts affecting corn plant namely - common rust caused by Puccinia sorghi, southern corn rust (SCR) caused by Puccinia polysora and tropical rust caused by Physopellazeae (Dolezal, 2011). Severity of common and southern rust is increased when incidence occurs earlier with a long lasting favourable weather condition for the disease development. Southern corn rust becomes more severe than common rust to field corn production because of its more aggressiveness and lack of resistance to most of the corn hybrids. Southern corn rust was not identified before 1941 in the western hemisphere but evidences of presence of it was there in the harberium specimen during 1879 (Cummins, 
1941). In 1949 Western Africa faced an outbreak of Southern corn rust which spreads across the continent and caused a considerable yield loss (Rhind et al., 1952). In 2000 infection of common rust was severe in the hybrid cornfields of Indiana (Kiersten Wise and Esker, 2008).

Of the three rusts that occur on corn (Zea mays L.) worldwide, southern rust of corn, caused by Puccinia polysora. Underw, has been reported as the most destructive among all the reported rusts of maize. $P$. ploysora differs from the common rust pathogen $P$. Sorghi Schw. Southern corn rust becomes progressively more severe as the plant develops, resulting in premature desiccation of plant tissues. SCR is considered as minor pathogen of corn but Yield losses of $45-50 \%$ was found due to epidemics and destruction was greatest in late-sown corn fields in 1972, 1973, 1974 and 1979 (Leonard, 1974; Futrell, 1975; Scott et al., 1979 and Schall et al., 1983). Southern rust of corn was also reported from Wisconsin (Pavgi et al., 1959) and Kansas (Sim, 1980). Sudden epidemics were also happened in double cropping of corn in lower Mississippi River Valley and on the coastal plain of the southeastern United States (Futrell, 1975; Widstorm and Young, 1980). In this double cropping system the first crop is planted in February and harvested in June, the second crop is planted in late June and harvested in October. This system provides the scope of infection of southern rust due to exposure of corn plants to large quantities of inoculums at its early growth stage. Favourable weather condition for southern corn rust prevails throughout the corn belt of United States (Hollier\& King 1985).

\section{Incidences of Southern corn rust}

This disease was first identified in 1941, first detection in Corn Belt during 1949. From 1949-1950s outbreaks were documented in
Africa and Asia (Philippines) and new races were also identified in eastern Africa. In 2006 Rpp9 virulent - anew race was identified.

Economic damage of southern corn rust: In USA reported upto $45-75 \%$, Africa more than $50 \%$ (1950s) and Philippines more than $80 \%$ (1956).

Presence of southern rust of maize (Zea mays L.) caused by Puccinia polysoraUnderw.in India was first confirmed in Mysore district of Karnataka. Moderate to severe infection of this rust was noticed in October 1999, during Post-Entry Quarantine Inspection (PEQI) of maize crop at Bangalore (Agarwal et al., 2001).

Identifying characters of southern corn rust are - pustules are mainly formed on upper leaf surface and occasionally some pustules are developed along the midrib of the bottom of the leaf, on the husk, orange to reddish-orange in color, develops in warm moist conditions. Urediniospores usually oblong, ellipsoid, mostly not round but immature spores round (Dolezal, 2011).

Sothern rust was found in corn fields of southwestern part of Georgia caused by Rpp9virulent Puccinia polysora and this was an unusual occurrence (Dolezal et al., 2009).

In Georgia differential reactions was found of $R p p$ resistance to an $R p p$-virulent isolate of Puccinia polysora (Pataky et al.,). Differential races of Puccinia polysora was proposed by Yeh in 1986. Variations among the isolates of Puccinia polysora was found in Brazil in 2002 by Casela \& Ferreira. Sources of resistance to Puccinia polysora was identified by Wisser et al., in 2006. Changes of races in Puccinia polysora is found in 2006. In Brazil uredial formation of several Rpp9 lines was identified in February, 2006. Widespread southern rust outbreak was happened in New York in the 
month of August, 2006. Significant uredial development was observed in hybrids containing the Rpp9 gene in Goias of Brazil during February, Puerto Vallarta of Mexico during March, in Victoria of Texas during June of 2007. Again detection of southern rust by using PCR was done in 2011 by Crouch and Szabo.

\section{Symptoms of southern cornrust}

Southern rust is caused by the fungus Puccinia polysora. Symptoms of southern rust are different from common rust in that they are typically smaller in size and are often a brighter orange color. Pustules of southern rust also typically only develop on Southern rust pustules on a corn leaf. The upper surface of the leaf becomes more affected. Southern rust is microcyclic in nature and believed to be autoecioushemiform. This type of rust is distributed worldwide in tropical and subtropical regions. Orange to tan circular or oval pustules commonly form in dense clusters on the upper leaf surface (Fig. 1). As the season progresses, the pustules can change to brown or black. Southern rust can be easily confused with other leaf diseases of corn such as common rust or Physoderma brown spot. Proper diagnosis helps to avoid unnecessary and costly fungicide applications (Geist, 2018). Sometimes this disease may come in later stage of crop and can cause major stalk lodging. Urediniospores of Puccinia polysora usually oblong, ellipsoid but most are not round and the teleutospores are having short pedicels which are 1/4th in length of spore. Teliospores are usually found in the field only late in season as the tissue starts to die and common in tropical regions. Sometimes they show a semicircular / horseshoe type or completely circular pattern. Optimum temperature for the germination of urediniospore is $23-28^{0} \mathrm{C}$ and $16 \mathrm{hrsdew}$ period is required for optimal infection (Dolezal et al., 2009).

\section{Difference between common rust and southern rust}

Cool, warm and moist weather $\left(15-25^{\circ} \mathrm{C}\right)$ is favorable for common rust but for southern rust hot, warm and moist weather $\left(25^{\circ} \mathrm{C}\right)$ is suitable. Pustules of common rust are large circular to elongated, brown to cinnamon brown but that of southern rust are small, circular, pinheaded and reddish orange.

Pustules are formed both on upper and lower surface and sparsely scattered in common rust and pustules are formed only on upper surface in densely cluster form in southern rust. Puccinia polysora differs from the common rust pathogen Puccinia sorghischw. SCR becomes more severe as the plant develops, resulting in premature desiccation of plant tissues (Scott et al., 1984).

\section{Conditions favoring disease development}

These fungi require living plant tissue to survive, so once the corn plant dies, the fungus loses its host. Most rust fungi are biologically complex (with many spore stages) and require more than one host species to complete their life cycles, which includes sexual reproduction. However, the spores produced on corn (urediniospores) are capable of indefinite asexual reproduction, as long as living corn is available to be infected. Each year, urediniospores of both rusts are blown north from tropical areas.

They are carried on wind currents and deposited into cornfields of USA. Favorable conditions for southern rust development include high humidity and temperatures around $8^{\circ} \mathrm{F}$. However, very little free moisture is need for infection to occur. Southern rust is typically a rare occurrence in Wisconsin but its occurrence is found usually in the southern and south-western portions of the state, epidemics initiating late in the season and in 
southern Wisconsin epidemic was happened in 2016 (Damon L. Smith, 2017).

Southern corn rust fungi require short periods of leaf wetness to cause infection. Approximately six hours of dew is usually enough moisture for infection and disease development. Temperature plays a critical role in the life cycle of this rust.

Southern rust prefers warmer weather fungal infection occurs between $77-82^{\circ} \mathrm{F}$. This disease usually appears in Indiana of USA in late August or September. When conditions are favorable for rust development, the infection cycle will continually repeat and result in secondary infections. Each pustule produces thousands of spores that can infect the plant and produce additional pustules within seven days. With continuation of these cycles, disease intensity can reach epidemic levels very quickly.

Corn rust can reach damaging levels at high speed and it is necessary to pay careful attention to the level and timing of initial disease infection in susceptible hybrids. Young leaves are more susceptible to southern rust infection than mature leaves, and lateplanted corn may be at greater risk for infection if rust spores reach to corn fields and weather conditions favour disease development.

\section{Disease impact}

Rust disease is responsible for economic loss in seed corn, sweet corn, and pop corn production. Among the three rusts affecting corn southern rust caused by Puccinia polysora Undrew. has been reported as the most destructive (Melching, 1975). Due to this disease attack, yield loss may be upto $45 \%$ $50 \%$ (Rodriguez et al., 1980). Destruction due to the attack of southern corn rust is more severe in late sown corn fields (Scott et al., 1976).
Yield loss due to SCR is significant when the disease appears early in the growing season or in case of corn planted late during the growing season. Critical yield loss is observed when infection occurred by early grain fill stages (Storey and Howland 1957, Futrell, 1975). Historic outbreaks of SCR occurred in Africa in 1949 and yield loss of around 50\% was reported (Rhind et al., 1952, Hemmingway, 1955 and Cammack, 1958). In Philippines, during 1953, Yield losses of 80 to $84 \%$ were observed on susceptible cultivars (Reyes, 1953) and substantial yield loss of 42 to 53\% was first reported in northern China in 1998 (Chen et al., 2004). Losses upto 18 and 39\% in SCR inoculated field trials conducted in Pennsylvania and Maryland (Raid, 1988). In Florida, yields reduction of corn planted in a double-cropped field was upto $45 \%$ due to SCR (Pernenzy, 1999).

Extent of yield loss depends on the timing of disease development and severity. Upto 45\% yield loss is reported from Florida due to severe outbreak of southern corn rust. For $10 \%$ leaf area infection, 6\% yield loss was recorded in Illinois sweet corn (Tamra and Jackson, 2014).

Rust diseases are parasites and divert nutrients for fungal growth that would normally be used by the plant. This process can lead to yield loss during grain filling stage when plant resources are needed to contribute to the developing ear.

Rust pustules also rupture leaf epidermal tissue, which can interfere with the regulation of water loss by stomata on the leaf surface.

Severe rust outbreaks may reduce the plant's water use efficiency and symptoms of mild drought stress are found in infected plants which may also help to the development of stalk rot and lodging. Southern rust has great impact on seed corn, sweet corn, and popcorn 
because of the inherent susceptibility of inbred and specialty hybrids.

Southern rust has the greatest potential to damage yield of corn in Indiana of USA at a critical point in the growing season. The importance of this disease has increased in southern states of USA and routinely reducing yields on susceptible hybrids without any fungicide application.

Southern rust of corn epidemic caused by Puccinia polysora was initiated in Maryland and Pennsylvania. The rust was more severe on lower leaves and the severity generally decreased with successive leaf positions. Grain yields were reduced $17.7 \%$ to $39.1 \%$ respectively at Pennsylvania and Maryland field sites. This maximum reduction occurred during 1984 at a $3 \mathrm{~m}$ distance from the inoculum source. The yield reduction was significantly related to the area under the disease progress curves as calculated from time 10 to 35 days after anthesis. Environmental data suggest temperature may be the factor most limiting to development of southern rust of corn in northern areas of the United States.

In 2008, a new genetic variant (race) of the southern rust fungus was discovered in Georgia that was able to cause disease on formerly resistant hybrids. This has increased the importance of the disease in southern areas of USA.

\section{Management}

By utilizing the Rpp9 gene and other sources of Rpp resistance have been successful for management of Southern Corn Rust in the United States for more than two decades (Pataky et al., 2010). Puccinia polysora is known to have multiple races to overcome single, dominant resistance genes (Hooker, 1985) but there are few recent studies focusing on identifying phenotypic virulence and genetic diversity of $P$. polysora.

Management of Southern Corn Rust (SCR) in Georgia by using fungicides is recommended since 2004 (Kemerait, 2012). It was started in response to the serious damages caused by severe outbreaks of Southern Corn Rust in 2003(Woodward, 2012). Fungicide applications are expected to be effective upto the dough stage of the corn crop, after that crop becomes safe from southern rust. Application of fungicides at the tasselling stage was effective to manage SCR and in protecting the yield of corn (Kemerait, 2012). Susceptible hybrids must be protected with fungicides, especially when the environment is favorable for disease development. Southern corn rust is a destructive disease in maize. The inbred line Qi319 is highly resistant to southern corn rust. The inheritance of resistance to southern rust in Qi319 was investigated (Chen et al., 2002) and considered that Qi319 carries one dominant gene for resistance to southern corn rust.

Traditionally resistance was used to manage southern rust of corn. In 2008 a resistancebreaking race of the southern rust fungus was confirmed in Georgia. Thus most modern hybrids are considered susceptible to southern rust. Rotation and residue management have no effect on the occurrence of southern rust. The southern rust fungus has to have living corn tissue in order to survive and cannot overwinter in Wisconsin. Fungicides are typically used to control southern rust in parts of the U.S. where this is a consistent problem (Damon L. Smith, 2017).

Biological control of SCR can be done by Sphaerellopsis sp. Which is a mycoparasite. Some Sphaerellopsis sp. isolates were assayed in vitro and inhibition of uredospore germination of $P$. polysora by 69 to $92 \%$ was found. In pot experiment, Sphaerellopsis sp. 
reduced the infection efficiency of $P$. polysora from $75-82 \%$ with the most virulent isolates. Uredospore production was reduced by $69 \%$. Sphaerellopsis $s p$. when applied in the field significant reduction of rust severity from $46 \%$ to $25 \%$ was obtained. Yield of dehusked green corn ears was increased from 4.688 ton/ha to 7.262 tons/ha (Paningbatan et al., 2000).

Fig.1 Symptoms, uredospores and teliospores of southern corn rust [(a) infected leaf in the field, (b)infected corn stalk in the field, (c) close up view of pustules on leaves), (d) uredospores, and (e-f)horseshoe teliospore]
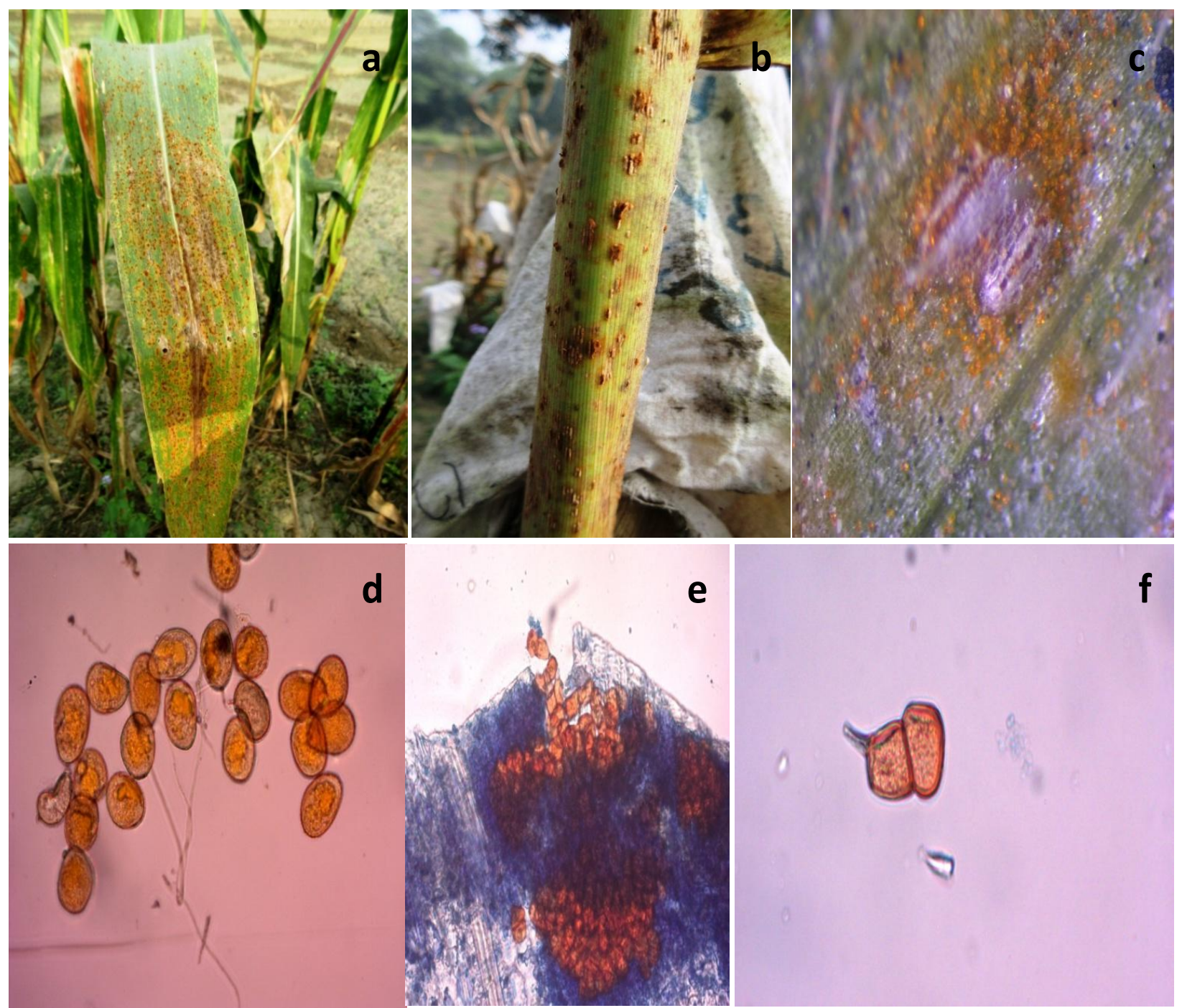

f 


\section{References}

Agarwal, P.C. Khetarpal, Ravi and Payak, M.M. (2001). Polysora rust of maize caused by Puccinia polysora and its spread in Karnataka. 71: 275-276.

Cammack, R. 1958. Studies on Puccinia polysoraunderw: I. The world distribution of forms of $P$. polysora. Transactions of the British Mycological Society 41: 89-94.

Casela,C. R. and Ferreira, A. S.. Variability in Isolates of Puccinia polysora in Brazil. Fitopatologia Brasileira 27: 414-416.

Chen CX, Yang DE, Wang ZL, Jin DM, Wang $\mathrm{HG}$, Wang B. Inheritance of resistance of southern corn rust in the inbred line Qi319.Yi Chuan Xue Bao. 2002 Oct; 29(10):903

Chen, C. X., Wang, Z. L., Yang, D. E., Ye, C. J., Zhao, Y. B., Jin, D. M., Weng, M. L., and

Wang, B. 2004. Molecular tagging and genetic mapping of the disease resistance gene RppQ to southern corn rust. Theor. Appl. Genet. 108:945-950.

Crouch J. A. and Szabo L.J. July, 2011. Time PCR Detection and Discrimination of the Southern and Common Corn Rust Pathogens Puccinia polysora and Puccinia sorghi. Plant Disease.

Cummins, G.B. 1941. Identity and distribution of three rusts of corn. Phytopathology, 31: 856-857.

Damon L. Smith. 2017. Corn and Southern Rust. Wisconsin Field Crops Pathology. Occurrence of southern rust, caused by Rpp9-virulent Puccinia polysora, on corn in southwestern

Dolezal, W., Tiwari, K., Kemerait, R., Kichler, J., Sapp, P., and Pataky, J. 2009. An unusual Georgia. Plant Dis. 93:676.

Dolezal, Wm. E. 2011. APS 2011. Field Crops Rust Symposium, San Ontonio, TX, Dec 14, 2011.
Futrell, M.C. 1975. Puccinia polysora epidemic on maize associated with cropping practice and genetic homogeneity. Phytopathology. 65: 1040-1042.

Hemingway, J. 1955. Effects of Puccinia polysora rust on yield of maize. East Afr. Ag. J. 20:191-194.

Esker, P. 2008. Estimating common rust on corn. Wisconsin Crop Manager 15(23): 1-2.

Hollier, C.A. and King,S.B.1985. Effects of temperature and relative humidity on germinability and infectivity of Puccinia polysora uredospores. Plant Dis. 69:937-939Hooker, A. L. 1985. Corn and sorghum rusts. The Cereal Rusts 2: 207-236.

Kemerait, R. C. 2012. Corn disease and nematode update for 2013. in: A Guide to Corn Production in Georgia 2013. The University of Georgia Cooperative Extension, Athens, GA

Kiersten Wise, Diseases of corn-common and southern rust, Perdue Extension, BP $82 \mathrm{~W}$.

Leonard, K.J. 1974. Foliar pathogens of corn in North Carolina. Plant Dis. Rep. 58: 532-534.

Melching, J.S.1975. Corn Rusts: Types, races and destructive potential. Pages 90 115. In: Proceedings of the $13^{\text {th }}$ Annual Corn and Sorghum Research Conference.

Paningbatan, R.A. Bastasa, G.N.Biological control of Puccinia polysora Under w. (corn rust) With Sphaerellopsis sp. [2000] Philippine Journal of Crop Science. V25(23).

Pataky, J.K.; Dolezal, W.E. and Brewbaker, J.L. Differential reactions of sources of $R p p$ resistance to an $R p p$-virulent isolate of Puccinia polysora.

Pataky, J. K., Dolezal, W. E., and Brewbaker, J. L. 2010. Differential reactions of sources of Rpp-resistance to an Rpp- 
virulent isolate of Puccinia polysora. Phytopathology 100: S98.

Pavgi,M.S. and Flangas, A.L. 1959. Occurrence of southern corn rust in Wisconsin. Plant Dis. Rep.43:12391240.

Pernezny, K., and Kucharek, T. 1999. Rust diseases of several legumes and corn in Florida. Department of Plant Pathology, Florida Cooperative Extension, Gainsville, FL.

Reyes, G. M. 1953. An epidemic outbreak of the maize rust in Eastern and Central Visayas, Philippines. The Philippine Journal of Agriculture 18:115.

Raid, R. N. 1988. Puccinia polysora epidemics in Pennsylvania and Maryland. Phytopathology 78:579585.

Rhind,D; Waterson,J.M. and Deighton, F.C.1952.Occurrence of Puccinia polysora Undrew. In West Africa. Nature (London). 169: 631.

Rodriguez-Ardon, R; Scott, G.E. and king, S.B. 1980. Maize yield losses caused by southern corn rust. Crop Sci. 20:812-814.

Schall, R.A., MacCain, J.W. and Hennen, J.F. 198. Distribution of Puccinia polysora in Indiana and absence of a cool weather form as determined by comparison with $P$. sorghi. Plant Dis. 67: 767-770.
Scott, G.E. and Futrell, M.C. 1976. Southern corn rust. Crop. Soil. Mag. April-may: 16-18.

Sim IV.T. 1980. Southern rust of corn recognized in Kansas. Plant Dis. 64:500

Scott, G.E; King, S.B. and Armour, J.W. Jr. 1984. Inheritance of resistance to southern corn rust in maize populations. Crop Sci. 24: 265-267.

Storey, H. H., and Howland, A. K. 1957. Resistance in maize to the tropical American rust fungus Puccinia polysora. Heredity 13: 61-65.

Tamra, A.; Ziems, Jackson. Rust Diseases of corn in Nebraska, 2014. Nebguide, G1680, University of Nebraska, Lincon.

Widstorm, N.W. and Young, J.R.1980. Double cropping corn on the coastal plain of the southeastern United states. Agron. J. 72: 302-305.

Wisser, R. J., Balint-Kurti, P. J. and Nelson, R.J. 2006. Sources of Resistance $-P$. polysora. Phytopath. Vol. 96, No. 2, 120-129

Woodward, J. W., ed. 2012. 2003 Georgia Plant Disease Loss Estimates. The University of Georgia Cooperative Extension, Athens, GA.

Yeh, C.C.; 1986. Studies on rusts of maize. Journal of Agricultural Research Of China 35: 81-93.

\section{How to cite this article:}

Srabani Debnath, Sanjog Chhetri and Sonali Biswas. 2019. Southern Rust Disease of Corn - A Review. Int.J.Curr.Microbiol.App.Sci. 8(11): 855-862. doi: https://doi.org/10.20546/ijcmas.2019.811.101 